\title{
129 Mouse
}

National Cancer Institute

\section{Source}

National Cancer Institute. 129 Mouse. NCI Thesaurus. Code C15151.

Inbr and colour depends on substrain (see below). Origin: Dunn 1928 from crosses of coat colour stocks from Eng lish fanciers and a chinchilla stock from Castle. This strain has a common orig in with strain 101. Most substrains carry the white-bellied agouti gene AW though only a subset have the agouti pattern as many carry albino or chinchilla and/or the pink-eyed dilution gene, $\mathrm{p}$, which is derived from Asian mice of the Mus musculus type (see also strains SJL, P/J and FS/Ei). (Jackson Labs/Festing) 